M. A. KomisArenko, O. M. KoshoviY, Yu. N. AvidZBA

National University of Pharmacy, Kharkiv National Medical University

\title{
STUDIES OF COMPOUND OF DERIVATIVES OF HYDROXYCINNAMIC ACIDS AND COUMARINS IN CRANBERRY'S LEAVES BY HPLC
}

There was studied the chemical composition of coumarins and derivatives of hydroxycinnamic acid of cranberry's leaves. In the cranberry's leaves there were revealed 2 coumarins - umbelliferon, skopoletin; 4 phenolcarbonic and hydroxycinnamic acids - coffee, rosemary, p-coumarinic, chlorogenic and set their contents.

Key words: cranberry; leaves; coumarin; HPLC

\section{INTRODUCTION}

Decoction of cranberry's leaves is used in the traditional and official medicine as a highly effective drug for the treatment of kidney and urinary tract. But this pharmaceutical form has several disadvantages: difficulty in preparation, lack of standardization, the inability to longterm storage, incomplete extraction of biologically active substances from medicinal plants. So it's important to create a new standardized drug which will be based on biologically active substances of cranberry's leaves [4].

The main group of substances, which has pharmacological effect in a cranberry's leaves, are phenolic compounds. Earlier we reported on qualitative and quantitative determination of the chemical compound some classes of BAS in the leaves and extracts of leaves of cranberry: simple phenols hydroxycinnamic acid derivatives, the amount of flavonoids, the amount of phenolic compounds and organic acids [2, 3, 4]. Continuing research BAS cranberry's leaves and their products, we noticed that the individual content of hydroxycinnamic acid derivatives and coumarins in cranberry's leaves was not investigated. The aim was to investigate the composition of coumarins and derivatives of hydroxycinnamic acid cranberry's leaves.

\section{MATERIALS AND METHODS}

The object of the study was the cranberry's leaves, which was bought at the pharmacy (series 0715, a manufacturer by "Phyto Svit").

Preparing samples for analysis of plant material. The exact weight of the sample material was crushed carefully, than was placed in a round bottom flask of $100 \mathrm{ml}$, it was extracted with $50 \mathrm{ml}$ of $60 \%$ methanol solution for $15 \mathrm{~min}$ in a boiling water bath with reverse refrigerator while stirring. Then the sample is treated with ultra-

(c) Komisarenko M. A., Koshoviy O. M., Avidzba J. N, 2016 sound for $10 \mathrm{~min}$, filtered, quantitatively transferred to a volumetric flask of $100 \mathrm{ml}$, dilute to the mark with $60 \%$ methanol [5].

Preliminary analysis of hydroxycinnamic acids was performed by TLC in the system anhydrous formic $\mathrm{P}$ - water $\mathrm{P}$ - acetate $\mathrm{P}(8: 8: 84)$ compared with authentic samples. There were identified chlorogenic and caffeic acids, which had a blue fluorescence under UV light.

To separate the amount of phenolic compounds into individual components it was used HPLC on chromatograph Agilent 12003 D LC System Technologies (USA), which is equipped with a flow vacuum degasser G1322A, four channel pump gradient of low pressure G13111A autosampler (automatic injector) G1329A, thermostat of columns G 1316A, diodnomatrychnyy G1315S and refractometric G1362A detectors.

Method of determination. There was complied reversed-phase chromatography, used chromatography column SupelcoDiscovery C18 measure $250 \times 4.6 \mathrm{~mm}$ with sorbent: modified silica gel by oktadetsyl groups, which has a diameter of $5 \mathrm{mkm}$. As mobile phase it was used: solvent $\mathrm{A}$, which is $95 \%$ of the mix of mobile phase $0.005 \mathrm{~N}$ orthophosphoric acid and $5 \%$ solvent B - acetonitrile. Mode of chromatography: maximum feed rate of the mobile phase is $0.7 \mathrm{ml} / \mathrm{min}$, eluent working pressure is $10000-12000 \mathrm{kPa}$; column thermostat temperature is $25^{\circ} \mathrm{C}$; sample volume injected is $5-20 \mathrm{ml}$, chromatography time is $50 \mathrm{~min}$. Mode of elution is gradient: 0 min $95 \%$ solvent "A", $5 \%$ solvent "B"; 8 min $92 \%$ solvent "A" $8 \%$ solvent "B"; 15 min $90 \%$ solvent "A", $10 \%$ solvent "B"; 40 min $60 \%$ solvent "A", $40 \%$ solvent "B"; 41-42 min $25 \%$ solvent " $A$ ", $25 \%$ solvent "B"; $43-50$ min $95 \%$ solvent "A", $5 \%$ solvent "B"; scan time is 0.6 seconds, the detection range is $190-400 \mathrm{~nm}$.

To select the optimal analytical detection waves it has been studied ultraviolet spectra of existing standards of hydroxycinnamic acids. Based on these data detection of 


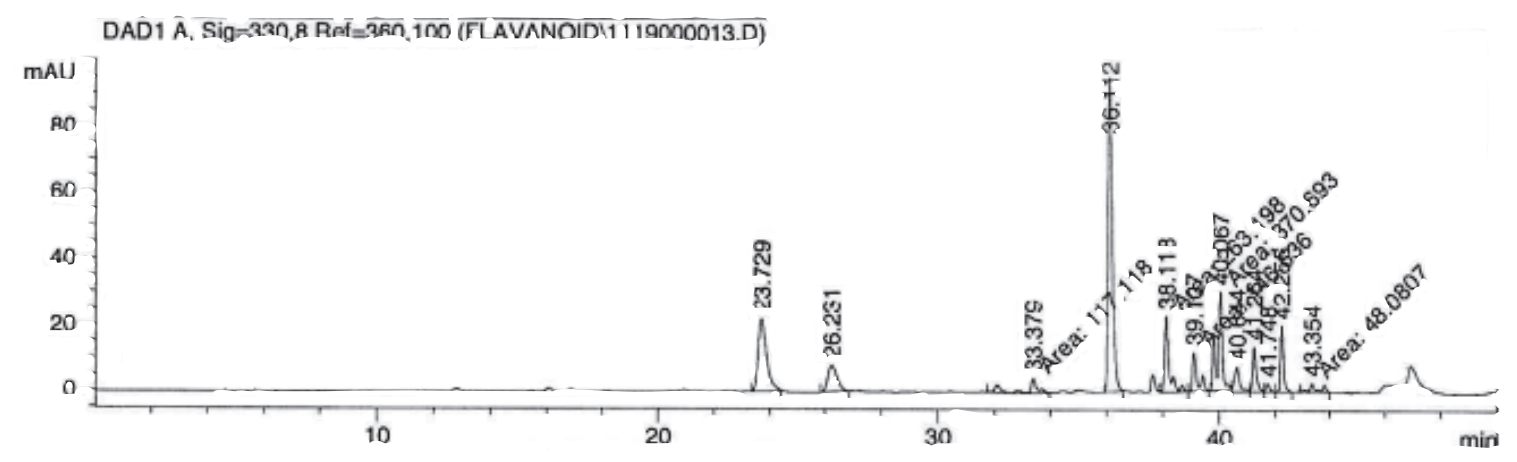

Fig. Chromatogram hydroxycinnamic acids and coumarins of cranberry's leaves

hydroxycinnamic acids in HPLC study conducted at a wavelength of $330 \mathrm{~nm}$ and $320 \mathrm{~nm}$. The calculation of the concentration of substances was carried by the area peaks using external standard method.

\section{RESULTS AND DISCUSSION}

In the cranberry's leaves there was revealed phenolic compounds: coumarin - umbelliferon (0.02\%), skopoletin $(0.05 \%)$; phenolcarbonic and hydroxycinnamic acids - coffee (0.03\%), rosemary $(0.1 \%)$, n-coumarinic (0.009\%), chlorogenic (0.16\%) (Fig.).

\section{CONCLUSIONS}

There was studied the qualitative and quantitative composition of hydroxycinnamic acids and coumarins of cranberry's leaves. Umbelliferon content was $0.02 \%$, skopoletin - $0.05 \%$; coffee acid - $0.03 \%$; rosemary acid $0.1 \%$; n-coumarinic - $0.009 \%$; chlorogenic acid - $0.16 \%$. The results indicate the perspectives of development new drugs which will be based on biologically active substances of cranberry's leaves and need for better studying of the phenolic compounds of this type of material. The data can be used to standardize the cranberry's leaves.

\section{REFERENCES}

1. Буданцев А. Л. Розмариновая кислота: источники и биологическая активность / А. Л. Буданцев, Е. Е. Лесиовская // Растит. ресурсы. - 2012. Т. 48, вып. 3. - С. 453-468.
2. Комісаренко М. А. Дослідження амінокислотного складу спиртового екстракту з листя Брусниці звичайної / М. А. Комісаренко, О.М.Кошовий, Г. П. Зайцев, А. М. Ковальова // Зб. наук. праць співробіт. НМАПО ім. П. Л. Шупика. - 2015. C. 127-131.

3. Комісаренко М. А. Досліждення органічних кислот листя Vaccinium vitis-idaea / М. А. Комісаренко, О. М. Кошовий, А. М. Ковальова, Н. В. Сидора // Зб. наук. праць спів робіт. НМАПО ім. П. Л. Шупика. - 2014. - Вип. 23, кн. 4. - С. 291-295.

4. Комісаренко М. А. Дослідження фенольних сполук спиртового екстракту з листя брусниці звичайної / М. А. Комісаренко, А. С. Гейдеріх, А. М. Ковальова, О. М. Кошовий // Укр. журн. клін. та лабораторної медицини. - 2012. - № 2. - С. 24-26.

5. Медведев Ю. В. Исследование содержания фенолокислот в лекарственном и пищевом растительном сырье методом ВЭЖХ: автореферат дис. ... канд. фармац. наук: 14.04 .02 «Фармацевтическая химия, фармакогнозия» / ГОУ ВПО Московская медицинская академия им. И. М. Сеченова. - М., 2010. - 24 с.

6. Фролов В. М. Оптимізація фітотерапії хронічного пієлонефриту / В. М. Фролов, Т. П. Гарник, В. С. Гришина // Фітотерапія. - 2006. - № 4. - C. 32-35.

7. Modnicki D. Potential sources of rosmarinic acid / D. Modnicki, I. Matławska // Herba Polonica. - 2007. - Vol. 53, № 2. - P. 165-166. 
УДК 615.322: 582.912.46: 581.45

М. А. Комиссаренко, О. Н. Кошевой, Ю. Н. Авидзба

ИССЛЕДОВАНИЕ СОСТАВА ПРОИЗВОДНЫХ ГИДРОКСИКОРИЧНОЙ КИСЛОТЫ И КУМАРИНОВ

В ЛИСТЬЯХ БРУСНИКИ МЕТОДОМ ВЭЖХ

Исследован химический состав кумаринов и производных гидроксикоричной кислоты листьев брусники обыкновенной. В листьях брусники обнаружены 2 кумарина - умбеллиферон, скополетин; 4 фенолкарбоновые и гидроксикоричные кислоты - кофейная, розмариновая, n-кумаровая, хлорогеновая и установлено их содержание.

Ключевые слова: брусника; листья; кумарины; ВЭЖХ

\section{УДК 615.322: 582.912.46: 581.45}

М. А. Комісаренко, О. М. Кошовий, Ю. Н. Авідзба

ДОСЛІДЖЕННЯ СКЛАДУ ПОХІДНИХ ГІДРОКСИКОРИЧНОЇ КИСЛОТИ ТА КУМАРИНІВ У ЛИСТІ БРУСНИЦІ МЕТОДОМ ВЕРХ

Досліджено хімічний склад кумаринів та похідних гідроксикоричної кислоти листя брусниці звичайної. В листі брусниці виявлені 2 кумарини - умбеліферон, скополетин; 4 фенолкарбонові та гідроксикоричні кислоти - кавова, розмаринова, п-кумарова, хлорогенова та встановлено їх вміст.

Ключові слова: брусниця; листя; кумарини; ВЕРХ

Адреса для листування:

61168, м. Харків, вул. Валентинівська, 4.

Національний фармацевтичний університет
Надійшла до редакції 14.11.2016 р. 